\title{
Nuclear waste vitrification efficiency: cold cap reactions
}

Prepared for the U.S. Department of Energy

Assistant Secretary for Environmental Management

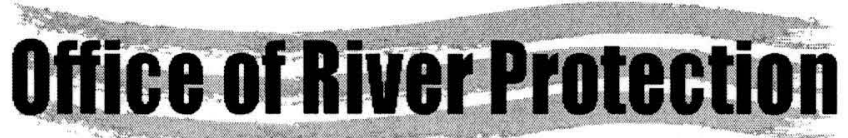

P.O. Box 450

Richland, Washington 99352 
ORP-49512-FP

Revision 0

\section{Nuclear waste vitrification efficiency: cold cap reactions}

P. R. Hrma

Pacific Northwest National Laboratory

R. Pokorny

Institute of Chemical Technology, Prague

Czech Republic

Date Published

August 2011

To Be Presented at

The 19th University Conference on Glass Science: Glasses for Energy

Rensselaer Polytechnic Institute \& The American Ceramic Society

Troy, New York

August 2-5, 2011

Published in

Journal of Non-Crystalline Solids

Prepared for the U.S. Department of Energy

Assistant Secretary for Environmental Management

\section{Office of River Protection}

\section{P.O. Box 450}

Richland, Washington 99352

\section{Copyright License}

By acceptance of this article, the publisher and/or recipient acknowledges the U.S. Government's right to retain a nonexclusive, royalty-free license in and to any copyright covering this paper.

\author{
A. A. Kruger \\ Department of Energy - Office of River Protection
}


ORP-49512-FP

Revision 0

LEGAL. DISCLAIMER

This report was prepared as an account of work sponsored by an agency of the United States Government. Neither the United States Government nor any agency thereof, nor any of their employees, nor any of their contractors, subcontractors or their employees, makes any warranty, express or implied, or assumes any legal liability or responsibility for the accuracy, completeness, or any third party's use or the results of such use of any information, apparatus, product, or process disclosed, or represents that its use would not infringe privately owned rights. Reference herein to any specific commercial product, process, or service by trade name, trademark, manufacturer, or otherwise, does not necessarily constitute or imply its endorsement, recommendation, or favoring by the United States Government or any agency thereof or its contractors or subcontractors. The views and opinions of authors expressed herein do not necessarily state or reflect those of the United States Government or any agency thereof.

This document is available to the U.S. Department of Energy and its contractors, in paper from the Office of Scientific and Technical Information (OSTI). It is available for sale to the public from the National Technical Information Service (NTIS).

This report has been reproduced from the best available copy. Available in paper copy. 


\title{
Nuclear waste vitrification efficiency: cold cap reactions
}

\author{
P. Hrma ${ }^{(\mathrm{a}) *}$, A.A. Kruger ${ }^{(\mathrm{b})}$, R. Pokorny ${ }^{(\mathrm{c})}$
}

(a) Division of Advanced Nuclear Engineering, Pohang University of Science and Technology, Republic of Korea, and Pacific Northwest National Laboratory, Richland, Washington, USA, 99352

${ }^{(b)}$ U.S. Department of Energy Hanford Tank Waste Treatment and Immobilization Plant Federal

Project Office, Engineering Division, Richland, Washington, USA, 99352

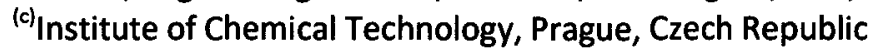

${ }^{*}$ Corresponding author

The cost and schedule of nuclear waste treatment and immobilization are greatly affected by the rate of glass production. Various factors influence the performance of a waste-glass melter. One of the most significant, and also one of the least understood, is the process of batch melting. Studies are being conducted to gain fundamental understanding of the batch reactions, particularly those that influence the rate of melting, and models are being developed to link batch makeup and melter operation to the melting rate.

Batch melting takes place within the cold cap, i.e., a batch layer floating on the surface of molten glass. The conversion of batch to glass consists of various chemical reactions, phase transitions, and diffusion-controlled processes. These include water evaporation (slurry feed contains as high as $60 \%$ water), gas evolution, the melting of salts, the formation of borate melt, reactions of borate melt with molten salts and with amorphous oxides $\left(\mathrm{Fe}_{2} \mathrm{O}_{3}\right.$ and $\left.\mathrm{Al}_{2} \mathrm{O}_{3}\right)$, the formation of intermediate crystalline phases, the formation of a continuous glass-forming melt, the growth and collapse of primary foam, and the dissolution of residual solids. To this list we also need to add the formation of secondary foam that originates from molten glass but accumulates on the bottom of the cold cap.

This study presents relevant data obtained for a high-level-waste melter feed and introduces a one-dimensional (1D) mathematical model of the cold cap as a step toward an advanced threedimensional (3D) version for a complete model of the waste glass melter. The $1 \mathrm{D}$ model describes the batch-to-glass conversion within the cold cap as it progresses in a vertical direction. With constitutive equations and key parameters based on measured data, and simplified boundary conditions on the cold-cap interfaces with the glass melt and the plenum space of the melter, the model provides sensitivity analysis of the response of the cold cap to the batch makeup and melter 
conditions. The model demonstrates that batch foaming has a decisive influence on the rate of melting. Understanding the dynamics of the foam layer at the bottom of the cold cap and the heat transfer through it appears crucial for a reliable prediction of the rate of melting as a function of the melter-feed makeup and melter operation parameters. Although the study is focused on a batch for waste vitrification, the authors expect that the outcome will also be relevant for commercial glass melting.

\section{Introduction}

The cold cap, or batch blanket, is the layer of glass batch floating on molten glass in an electrical glass-melting furnace (a melter). In melters producing commercial glasses, the batch is typically spread in a layer of uniform thickness on the whole top surface area of the melt. In melters for nuclear waste glass, the melter feed, typically a slurry containing $40-60 \%$ water, is charged through one or more nozzles. The cold cap covers $90-95 \%$ of the melt surface. Mathematical models of melters have been well developed [1-5] in all aspects except for the batch melting, which has rarely been addressed in other than a simplified manner [6-12].

This work presents an initial step toward the modeling of a cold cap in a melter for high-levelwaste glass while taking advantage of the availability of data for the key properties and the reaction kinetics for a high-alumina melter feed [13-16] considered for the Waste Treatment and Immobilization Plant, currently under construction at the Hanford Site in Washington State, USA. The 1D model is based on the ideas by Hrma [9] and Schill $[10,11]$.

Though the 1D modeling greatly simplifies mathematical treatment, the main challenge lies in the complexity of the conversion process, which consists of a host of phenomena: water evaporation, gas evolution, melting of salts, borate melt formation, reactions of borate melt with molten salts and amorphous solids, precipitation of intermediate crystalline phases, formation of a continuous glassforming melt, growth and collapse of primary foam, dissolution of residual solids, and the formation of secondary foam at the bottom of the cold cap. In the present model, this complex situation is 
simplified by assuming that the feed consists of two major phases, the condensed phase and the gas phase.

The authors expect that the 1D two-phase model presented in this paper will be extended in the future to a two-dimensional (2D) multi-phase model to be incorporated in a complete 3D model of the waste glass melter.

\section{Theory}

The 1D model views the cold cap as a blanket of uniform thickness that receives steady uniform heat fluxes from both the molten glass below and the plenum space above (Fig. 1). The mass balances of the condensed phase and the gas phase are

$$
\begin{aligned}
& \frac{d \rho_{b}}{d t}+\frac{d\left(\rho_{b} v_{b}\right)}{d x}=r_{b} \\
& \frac{d \rho_{g}}{d t}+\frac{d\left(\rho_{g} v_{g}\right)}{d x}=r_{g}
\end{aligned}
$$

where $t$ is the time, $\rho$ the spatial density, $v$ the velocity, $r$ the mass source associated with reactions, and the subscripts $b$ and $g$ denote the condensed phase and the gas phase, respectively. The mass fluxes, $j_{b}$ and $j_{g}$, respectively, are $j_{b}=-\rho_{b} v_{b}$ (the minus sign in is used because the condensed phase moves in the negative direction) and $j_{g}=\rho_{g} v_{g}$. The energy balance for the condensed phase is:

$$
\rho_{b} c_{b} \frac{d T_{b}}{d t}=-\rho_{b} v_{b} c_{b} \frac{d T_{b}}{d x}-\frac{d q_{b}}{d x}+H+s
$$


where $T$ is the temperature, $c$ is the heat capacity, $q$ is the heat flux, $H$ is the internal heat source, and. $s$ is the heat transfer between phases. The heat flux is subjected to Fourier's law, $q_{b}=-\lambda^{E f f} \frac{d T}{d x}$, where the effective value of heat conductivity, $\lambda^{E f f}$, involves both conductive and radiative modes of heat transfer in the feed.

The boundary conditions are given in the term of both fluxes and temperatures, i.e., $q_{b}(0)=Q_{B}$, $q_{b}(h)=Q_{T}, T(0)=T_{B}$, and $T(h)=T_{T}$, where $h$ is the cold cap thickness, $T_{B}$ and $T_{T}$ are the bottom and top cold-cap temperatures, respectively, and $Q_{B}$ and $Q_{T}$ are the heat fluxes to cold-cap bottom and from cold-cap top, respectively.

To solve the energy balance equation, we used, for the sake of simplicity and comprehensibility, the finite difference method. For numerical simulations, experimental data were used together with constitutive equations that were taken from the literature and modified for our problem as described in Section 3. All algorithms were coded in Mathworks ${ }^{\circledR}$ MATLAB ${ }^{\circledR} 7$.

\section{Material Properties}

The melter feed composition is shown in Table 1.

Fig. 2 shows the degree of conversion, $\xi_{g}$, calculated as $\xi_{g}(T)=\left(m-m_{F}\right) /\left(m_{M}-m_{F}\right)$, where $m$ is the temperature-dependent feed mass, $m_{F}$ is the melter-feed mass, and $m_{M}$ is the glass mass; the subscript $g$ indicates that the degree of conversion is based on the release of gas from the feed. Because the $\xi_{g}(T)$ function changed little with the rate of heating, we used the degree of conversion obtained by thermogravimetric analysis at the heating rate $15 \mathrm{~K} \mathrm{~min}^{-1}$.

Following Schill [11], the heat capacity of the gas phase $\left(c_{\mathrm{g}}\right)$ was approximated by that of carbon dioxide: $c_{g}=1003+0.21 T-1.93 \cdot 10^{7} T^{-2}(T \geq 373 \mathrm{~K})$, where $c_{\mathrm{g}}$ is in $\mathrm{Jg}^{-1} \mathrm{~K}^{-1}$.

The melter feed density decreased as the temperature increased as a result of mass loss and the nearly constant volume of the sample at $T<\sim 700^{\circ} \mathrm{C}$, i.e., $\rho_{b}=\rho_{b o} \mathrm{~m} / \mathrm{m}_{F}$. Once the sample was shrinking between $\sim 700-800^{\circ} \mathrm{C}$, the density increased to a maximum. Then, above $800^{\circ} \mathrm{C}$, the density 
decreased as the bubbly melt turned to foam, reaching a minimum. The density was estimated from the expansion data reported in $[13,14]$.

For the heat conductivity, we used the relationship reported by Schill [17] for a high-level-waste melter feed: $\lambda^{E f f}=0.06571+0.002114 T(373 \mathrm{~K}<T<1000 \mathrm{~K})$, where $\lambda$ is in $\mathrm{W} \mathrm{m}^{-1} \mathrm{~K}^{-1}$. For $T>1000$ $K$, we used a linear interpolation between $\lambda^{E f f}$ at $1000 \mathrm{~K}$ and $\lambda^{E f f}\left(1100^{\circ} \mathrm{C}\right)=4.56 \mathrm{~W} \mathrm{~m}^{-1} \mathrm{~K}^{-1}$, the value for molten glass (Schill [17]). To the best of our knowledge, the heat conductivity of the foam layer at the cold cap bottom has not been determined experimentally. The heat conductivity of the foam layer was estimated to be close to half of the heat conductivity of bubble-free melt.

\section{Results}

As Fig. 1 illustrates, a layer of boiling slurry rests on the top of the cold cap, which consists of two layers: the main layer in which batch reactions occur and batch gases are escaping through open pores, and the bottom foam layer.

For the calculations, the cold-cap bottom temperature, $T_{B}=1100^{\circ} \mathrm{C}$, was estimated as the temperature at which the motion of the condensed phase can no longer be considered onedimensional and the circular convection of the melt takes over. The temperature at the interface between the cold cap and the slurry layer was $T_{T}=100^{\circ} \mathrm{C}$, the temperature of the boiling slurry pool, ignoring the elevation of the boiling point by dissolved salts.

Based on melter experiments reported by Matlack et al. [18], we chose as the baseline case a slurry feed containing $\mathbf{5 2 . 2}$ mass\% water and the glass production rate (the rate of melting) $j_{M}=$ $0.0141 \mathrm{~kg} \mathrm{~m}^{-2} \mathrm{~s}^{-1},\left(1220 \mathrm{~kg} \mathrm{~m}^{-2} \mathrm{day}^{-1}\right)$.

The major part of the total heat flux to convert the slurry to molten glass at $1100^{\circ} \mathrm{C}$ comes from the cold-cap bottom $\left(Q_{B}\right)$, of which a part enters the boiling slurry $\left(Q_{T}\right)$, while the remaining heat flows to boiling slurry from the plenum space $\left(Q_{u}\right)$. We have computed the temperature distributions within the cold cap as a function of two parameters: $Q_{F}$, the total heat flux to convert the slurry to $1100-{ }^{\circ} \mathrm{C}$ melt, and the fractional heat flux from above, $Q_{u} / Q_{s}$, where $Q_{s}$ is the heat flux to turn the 
slurry into dry feed. Fig. 3 compares the temperature distributions within the cold cap for three values of $Q_{u}$, while the total heat flux supplied to the slurry layer is constant. The profiles exhibit three intervals with distinct temperature gradients. Between 250 and $350^{\circ} \mathrm{C}$, the temperature gradient is affected by endothermic reactions. As Fig. 4 shows, most of the heat for melting is consumed in the upper part of the cold cap, 0.5 to $4 \mathrm{~cm}$ below the top surface. Within $350^{\circ} \mathrm{C}$ and $800^{\circ} \mathrm{C}$, the presence of molten phase results in an increased heat conductivity and a relatively mild temperature gradient as compared to the temperature interval of $800^{\circ} \mathrm{C}$ to $1100^{\circ} \mathrm{C}$, where a steeper temperature gradient is caused by the low $\lambda^{\text {eff }}$ of the foam layer.

Fig. 5 shows the condensed phase velocity versus the vertical position within the cold cap, $x$, for $Q_{u} / Q_{s}=0.8$. The higher velocity of the condensed phase in the foam layer results from the high porosity, while the lowest velocity occurs where the porosity is minimum; velocity changes little with $x$ in the upper part of the cold cap.

Fig. 6 displays the thickness of the cold cap as a function of $Q_{U} / Q_{S}$ for three values of $Q_{F}$, i.e., different rates of melting, showing that a higher melting rate makes the cold cap thinner.

\section{Discussion}

In the temperature interval of $700-800^{\circ} \mathrm{C}$ at which the density is minimum, a continuous layer of high-viscosity melt presents a barrier through which neither bubbles can ascend nor low-viscosity molten salts can drain. Therefore, an advanced cold-cap model, to be incorporated into the overall melter model, should describe at least two 2D phenomena, a horizontal flow of migrating molten salts and the horizontal movement of bubbles and cavities toward cold cap edges.

Foam continuously arises from batch reactions and redox reactions within molten glass. Foam has a low heat conductivity; thus, the foam layer hinders the heat transfer to the cold cap and leads to a lower melting rate [15]. However, because the rate of melting affects the cold-cap thickness, thus affecting the temperature gradient, (i.e., the heating rate that the feed experiences), the resulting shifts in the reaction peaks affect the rate of foaming [19]. Hence, a self-regulating 
mechanism exists that balances foaming, cold-cap thickness, and the heat fluxes from the top and bottom of the cold cap. Accordingly, batch foaming has a decisive influence on the rate of melting. Understanding the dynamics of the foam layer at the bottom of the cold cap and the heat transfer through it appears crucial for a reliable prediction of the rate of melting as a function of the melterfeed makeup and melter operation parameters.

The condensed phase contains a highly mobile molten salt. Horizontal migration of the salt melt can disrupt the steady state, leading to cold-cap freezing because of depletion of fluxes. Restoring the process requires melter idling, causing a loss of efficiency. A 2D model will determine the conditions for an uninterrupted steady state.

The cold-cap model presented is focused on a batch for waste vitrification. In a commercial electric glass melter, the top surface of the cold cap is dry, and, the top-surface boundary condition is not limited to $100^{\circ} \mathrm{C}$ as in a slurry-fed waste glass melter. Because the melting processes in both types of cold caps are similar in other aspects, the authors expect that the cold-cap model can be adapted for commercial glass melting.

\section{Conclusions}

1. At a constant total heat flux to the cold cap, the cold-cap thickness increases as the fraction of heat flux from above increases.

2. At a constant fractional heat flux from above, the cold-cap thickness decreases as the total heat flux to the cold cap increases.

3. As the cold-cap thickness changes, the reaction zone shifts, affecting the rate of foaming at the cold-cap bottom.

4. An advanced $2 \mathrm{D}$ cold-cap model should include behaviors of the main liquid and solid phases within the cold cap, and the foam layer under the cold cap. The model will be incorporated into the complete model of the melter. 


\section{Acknowledgements}

The authors are grateful to the U.S. Department of Energy Federal Project Office Engineering Division for the Hanford Tank Waste Treatment and Immobilization Plant for financial support. Richard Pokorny is also pleased to acknowledge support from Specific University Research (MSMT No. 21/2011). The authors would also like to thank their colleagues at the Pacific Northwest National Laboratory Dong-Sang Kim and Jaehun Chun for insightful discussions and David Pierce for providing thermogravimetric analysis and differential scanning calorimetry data. Pacific Northwest National Laboratory is operated for the U.S. Department of Energy by Battelle under Contract DE-AC0576RL01830. In its final stages, this research was supported by WCU (World Class University) program through the National Research Foundation of Korea funded by the Ministry of Education, Science and Technology (R31 - 30005).

\section{References}

[1] W.S. Kuhn, in: D. Krause, H. Loch (Eds.), Mathematical Simulation in Glass Technology, Springer (2002).

[2] C. Moukarzel, W.S. Kuhn, Glass Science and Technology 76 (2003) 81-90.

[3] Z. Feng, D. Li, G. Qin, S. Liu, J. Am. Ceram. Soc., 91 (2008) 3229-3234.

[4] A. Abbassi, Kh. Khoshmanesh, 28 (2008) 450-459.

[5] C.C. Yen, W.S. Hwang, Mater. Trans. 49 (2008) 766-773.

[6] H. Mase, K. Oda, J. Non-Cryst. Solids 38-39 (1980) 807-812.

[7] R. Viskanta, X. Wu, J. Am. Ceram. Soc. 67 (1984) 376-380.

[8] A. Ungan, R. Viskanta, AIChE Symposium Series, No. 236, Vol. 80 (1984) 446-451.

[9] P. Hrma, Glastechnische Berichte 55 (1982) 138-150.

[10] P. Schill, Ceram.-Silik. 26 (1982) 155-163.

[11] P. Schill, Ceram.-Silik. 26 (1982) 209-222.

[12] P. Schill, J. Chmelar, J. Non-Cryst. Solids 345 \& 346 (2004) 771-776.

[13] P. Hrma, M.J. Schweiger, C.J. Humrickhouse, J.A. Moody, R.M. Tate, T.T.Rainsdon, N.E. TeGrotenhuis, B.M. Arrigoni, J. Marcial, C.P. Rodriguez, B.H. Tincher, Ceram.-Silik. 54 (2010) 193-211.

[14] S.H. Henager, P. Hrma, K.J. Swearingen, M.J. Schweiger, J. Marcial, N.E. TeGrotenhuis, J. NonCryst. Solids 357 (2011) 829-835.

[15] D.A. Pierce, P. Hrma, J. Marcial, B.J. Riley, M.J. Schweiger, Int. J. Appl. Glass Sci., submitted.

[16] M.J. Schweiger, P. Hrma, C.J. Humrickhouse, J. Marcial, B.J. Riley, N.E. TeGrotenhuis, J. NonCryst. Solids 356 (2010) 1359-1367. 
[17] P. Schill, in: W. Lutze, Modeling the behavior of noble metals during HLW vitrification in the DM1200 melter, VSL-05R5740-1, Vitreous State Laboratory, The Catholic University of America, Washington DC (2005).

[18] K.S. Matlack, H. Gan, M. Chaudhuri, W. Kot, W. Gong, T. Bardakci, I.L. Pegg, J. Innocent, DM100 and DM1200 melter testing with high waste loading glass formulations for Hanford highaluminum HLW streams, VSL-10R1690-1, Vitreous State Laboratory, The Catholic University of America, Washington, DC (2010).

[19] F. Raether, M. Krauss, Glass Sci. Technol. 77 (2004) 118-123. 
Table 1.Melter feed composition (in g) to make $1 \mathrm{~kg}$ of glass.

\begin{tabular}{lr}
\hline Compound & \multicolumn{1}{c}{$\mathrm{g} / \mathrm{kg}$} \\
\hline $\mathrm{Al}(\mathrm{OH})_{3}$ & 367.49 \\
$\mathrm{SiO}_{2}$ & 305.05 \\
$\mathrm{~B}(\mathrm{OH})_{3}$ & 269.83 \\
$\mathrm{NaOH}$ & 97.14 \\
$\mathrm{Li}_{2} \mathrm{CO}$ & 38.30 \\
$\mathrm{Fe}(\mathrm{OH})_{3}$ & 73.82 \\
$\mathrm{CaO}$ & 60.79 \\
$\mathrm{NaF}$ & 14.78 \\
$\mathrm{Bi}(\mathrm{OH})_{3}$ & 12.80 \\
$\mathrm{Fe}\left(\mathrm{H}_{2} \mathrm{PO}_{2}\right)_{3}$ & 12.42 \\
$\mathrm{Na}_{2} \mathrm{CrO}_{4}$ & 11.13 \\
$\mathrm{NiCO}$ & 6.36 \\
$\mathrm{~Pb}_{3}\left(\mathrm{NO}_{3}\right)_{2}$ & 6.08 \\
$\mathrm{Zr}\left(\mathrm{OH}_{4}\right)_{4} \cdot 0.654 \mathrm{H}_{2} \mathrm{O}$ & 5.11 \\
$\mathrm{NaNO}_{3}$ & 4.93 \\
$\mathrm{Na}_{2} \mathrm{SO}_{4}$ & 3.55 \\
$\mathrm{NaNO}_{2}$ & 3.37 \\
$\mathrm{KNO}_{3}$ & 3.04 \\
$\mathrm{Zn}\left(\mathrm{NO}_{3}\right)_{2} \cdot 4 \mathrm{H}_{2} \mathrm{O}$ & 2.67 \\
$\mathrm{Na}_{2} \mathrm{C}_{2} \mathrm{O}_{4} \cdot 3 \mathrm{H}_{2} \mathrm{O}$ & 1.76 \\
${\mathrm{Mg}(\mathrm{OH})_{2}}^{\mathrm{Total}}$ & 1.69 \\
\hline & 1352.11 \\
\hline
\end{tabular}


Figure captions

Fig. 1.Cold-cap structure.

Fig. 2.Degree of conversion with respect to gas phase versus temperature and heating rate.

Fig. 3.Cold-cap temperature profile for three heat fluxes from plenum space.

Fig. 4.Effective heat capacity distributions within the cold cap.

Fig. 5.Velocity profile within the cold cap.

Fig. 6.Cold-cap thickness versus upper and total heat flux; numbers represent $Q_{\mathrm{F}}$ in $\mathrm{kW} \mathrm{m}^{-2}$. 


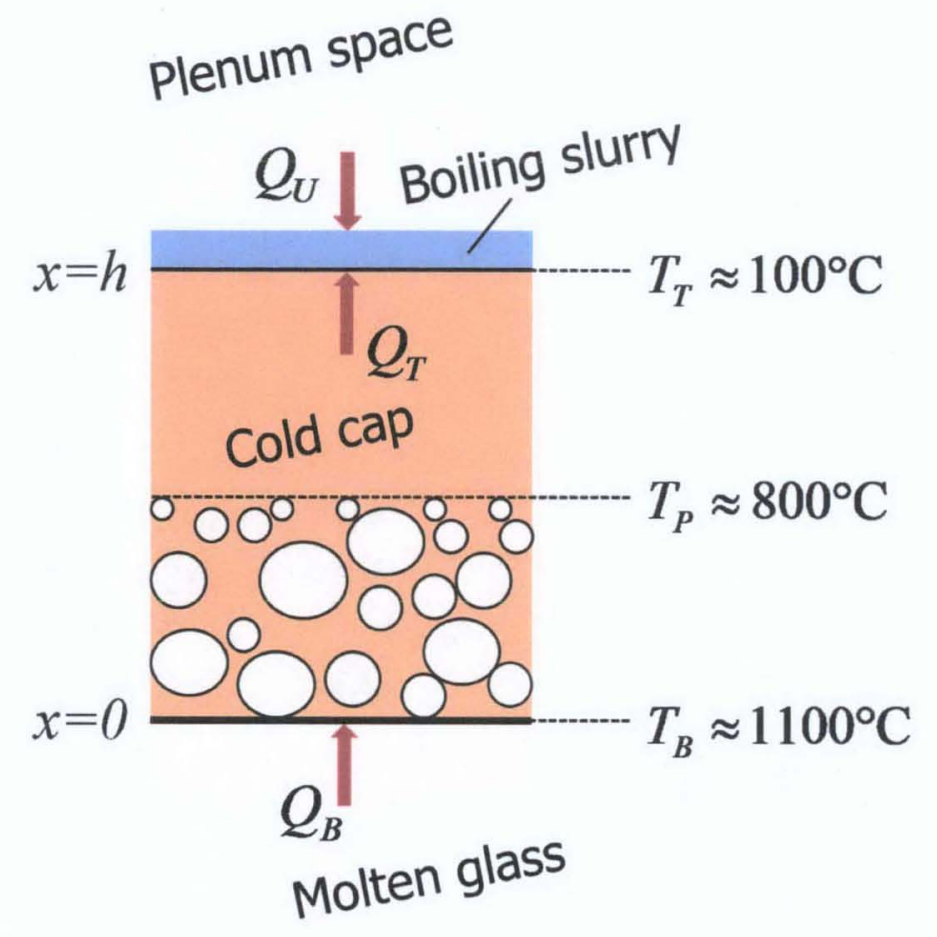

Fig. 1. 


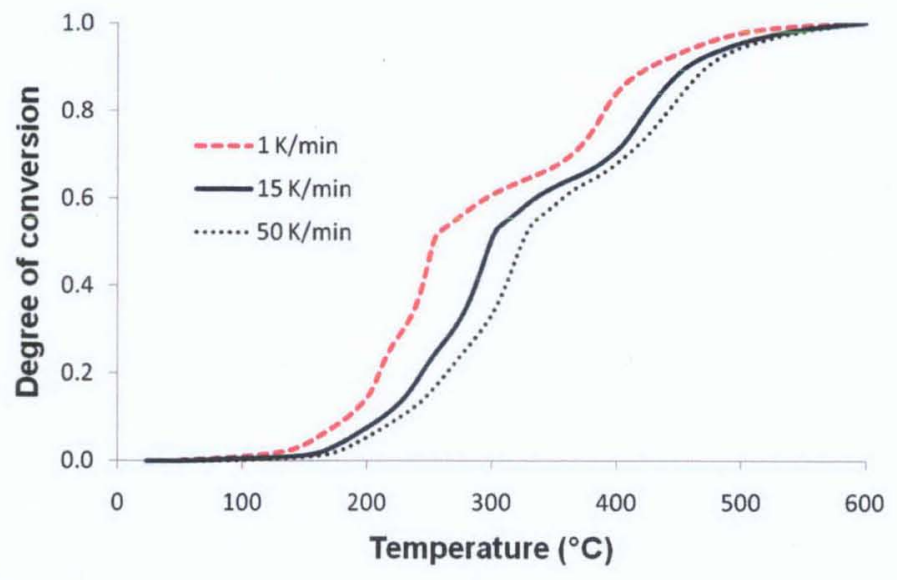

Fig. 2. 


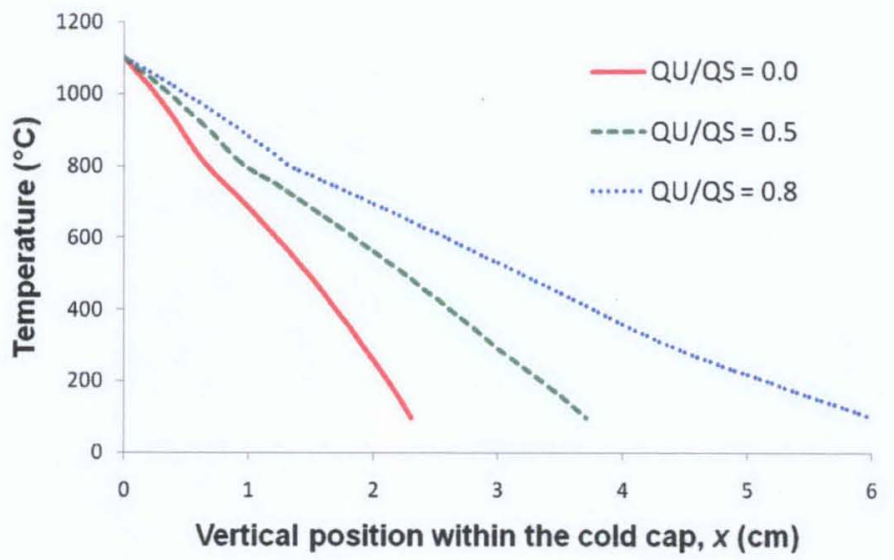

Fig. 3. 


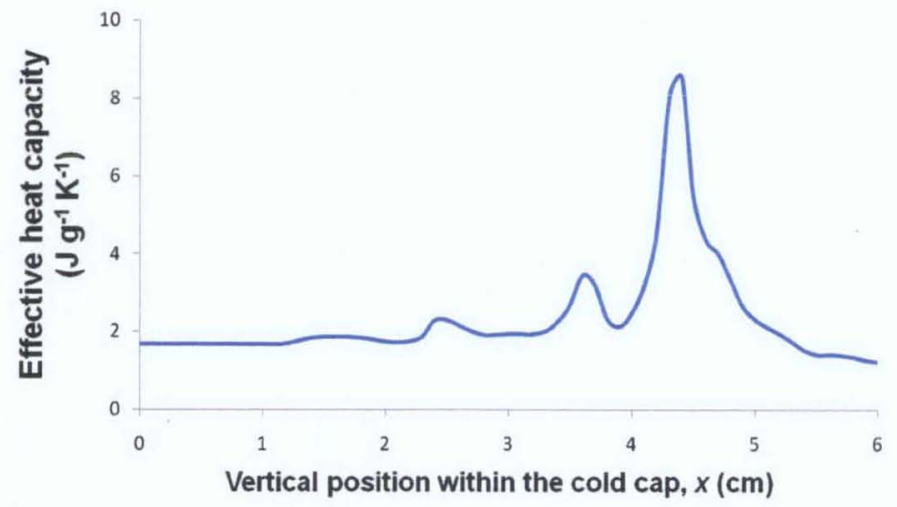

Fig. 4. 


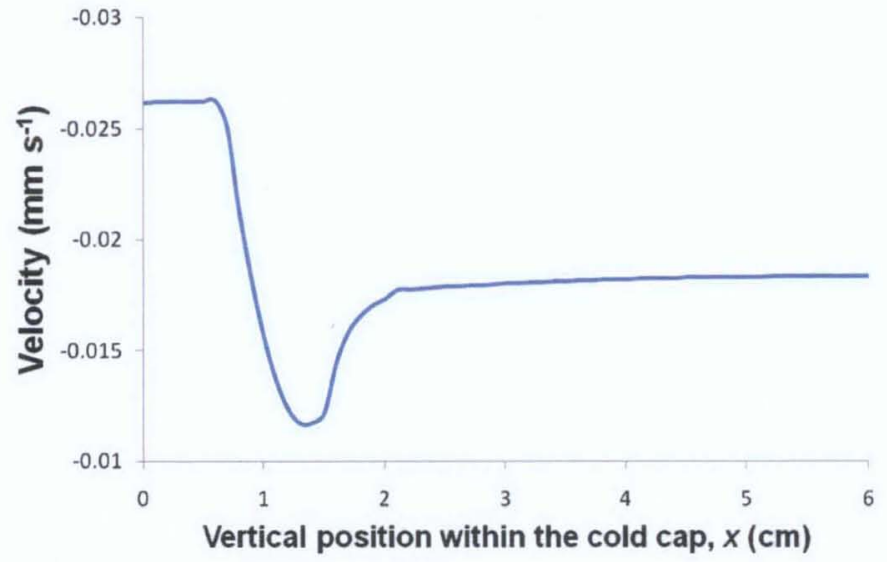

Fig. 5. 


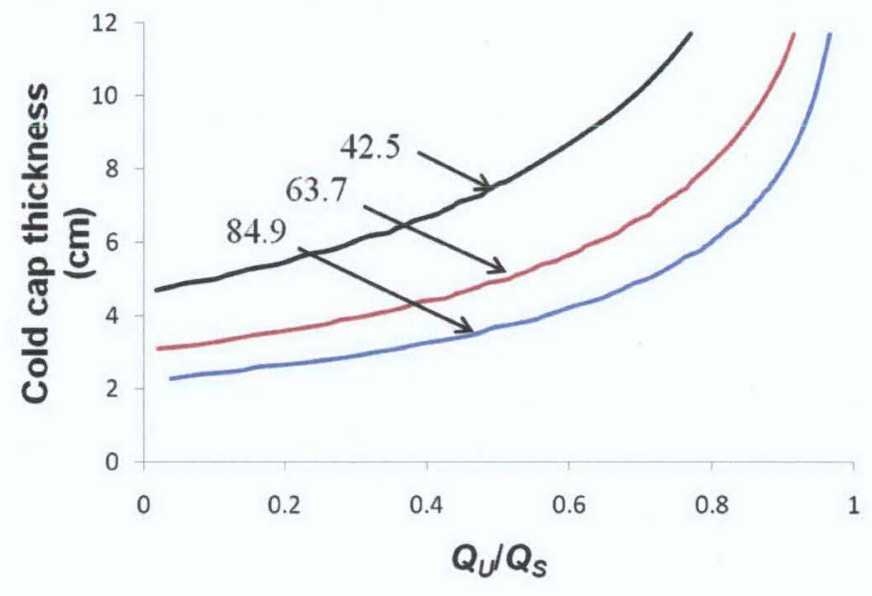

Fig. 6. 